\title{
Effect of Cross Wind Aerodynamic Force Variation on Stability of Vehicle Crossing Bridge Using a CFD Sliding Mesh Technique
}

\section{Abdulredha H. Aman ${ }^{1}$ and Mustafa S. Habib ${ }^{1,2}$}

${ }^{1}$ Department of Mechanical Engineering, University of Bahrain, Kingdom of Bahrain

${ }^{2}$ IEEE Member

\section{Abstract}

As far as ground vehicle lateral stability is concerned, aerodynamics in gusty crosswind conditions is of increased significance in the vehicle development process as well as bridges design and construction. Recent investigations demonstrated that unsteady aerodynamic loads can exceed steady loads considerably that may deteriorate driving lateral stability and may lead to loss of handling control. In order to compute and

Corresponding Author: Abdulredha H. Aman

Received: 18 September 2018 Accepted: 10 October 2018 Published: 15 October 2018

Publishing services provided by Knowledge

(c) Abdulredha H. Aman and Mustafa S. Habib. This article is distributed under the terms of the Creative Commons

Attribution License, which permits unrestricted use and redistribution provided that the original author and source are credited.

Selection and Peer-review under the responsibility of the Sustainability and Resilience Conference Committee. evaluate the vehicle response to a crosswind gusts, it is essential to determine the aerodynamic excitation on the vehicle body.

The present work is concerned with the lateral dynamic stability of ground vehicles while crossing severe gusty crosswind conditions. In this investigation, Shaikh Isa bin Salman Bridge is considered, due to its geometrical construction properties with regard to side wind pulse generation, as an example of such gusty crosswind conditions. In severe windy days, vehicles are exposed to disturbing pulsating crosswinds while crossing the Bridge. This leads to the drivers feeling that they lost control over their vehicle. Several accidents have been reported in local newspapers relating to the accidents to vehicle loss of lateral control.

This study focuses on the crosswind modelling of the bridge, to find the variation of the aerodynamic distribution pattern of various crosswind speeds and orientations, and their effect on the stability of driver-vehicle closed loop system.

Keywords: Aerodynamics, Road Vehicle handling, Crosswind, CFD, Vehicle Safety, Unsteady Aerodynamic Lateral Loads

\section{Nomenclature}

$\rho: \quad$ Density

$\mu$ : $\quad$ Dynamic viscosity

A: $\quad$ Area

G OPEN ACCESS
A: Area

Cp: Coefficient of pressure 


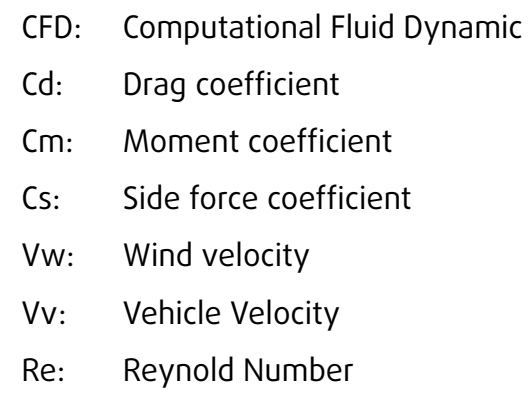

\section{Introduction}

Vehicle accidents have negative economic cost in properties, congestion and human lives. Handling characteristics of a road vehicles refer to their response to steering commands and to environmental inputs, such as wind gust and road disturbances which affect their lateral motion directional stability (Wong 2001).

High lateral winds are associated with a small proportion of crashes but generally increase the risk of traffic collisions (European Agency for Safety and Health at Work 2010). Wind gusts can push relatively high vehicles such as busses, delivery vans, camper vans, caravans, and lorries off course and, under extreme conditions, can even cause them to roll over. This happens mainly on bridges and viaducts (Institute for Road Safety Research 2012) Shaikh Isa bin Salman Causeway in the Kingdom of Bahrain connecting Busaiteen to the Diplomatic Area, opened to the public in January 1997. It can be recognized by its triangular white columns to symbolize sails (Haji Hassan ReadyMix 2012). These triangular columns shown in Figure 1 are the cause of generating wind turbulence through blocking the wind by the columns leading to nozzle effect between the columns.

Formal reports with statistics about accidents due to this problem have not been found, while local newspapers have reported traffic accidents while crossing the bridge in different dates of the year. Lost control have been reported which refer to different reasons including humans, environmental and /or vehicle malfunction, see Table 1.

Wind speed in the surrounding area can reach up to $30 \mathrm{~m} / \mathrm{s}$, measured in Bahrain International Airport, Wind speed reaches 25 knots (over $46 \mathrm{k} / \mathrm{h}$ ), in different direction. Alnaser and Al-Karaghouli(2000),

A Google Earth picture for the bridge attached with wind rose showing the direction and frequency of wind indicating wind attacking from northwest. Figure 2 Al Buflasa et al (2008). 


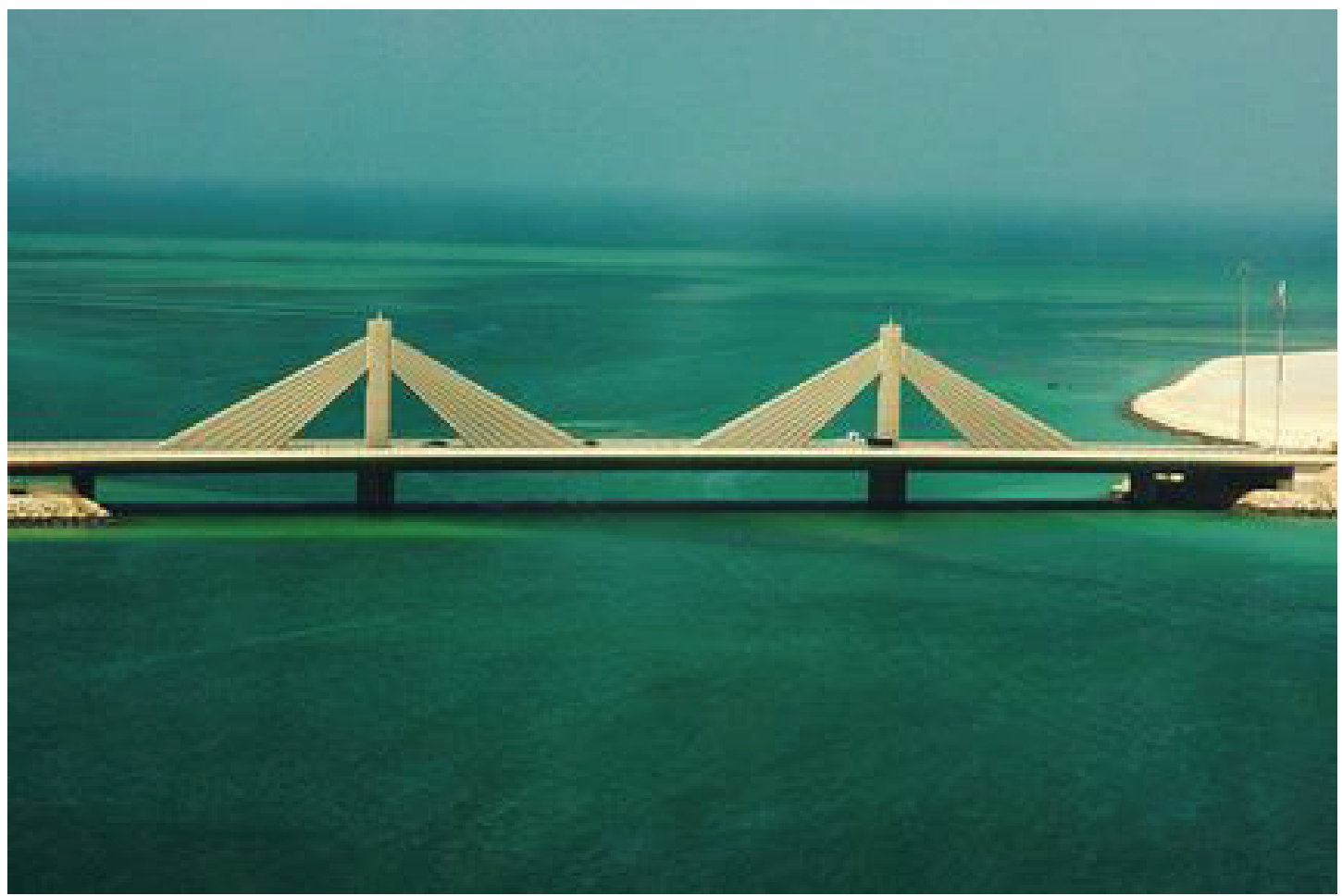

Figure 1: Triangular white columns of Shaikh Isa bin Salman Causeway (Haji Hassan ReadyMix 2012).

TABLE 2: Local newspaper accident reports on the bridge.

\begin{tabular}{|c|c|c|c|}
\hline \# & Date dd-mm-yyyy & Accident description & results \\
\hline 1 & $03-06-2003$ & $\begin{array}{l}1 \text { vehicle lost control, } \\
\text { cross to opposite } \\
\text { direction and hit light } \\
\text { pole and } 2 \text { vehicles }\end{array}$ & 4 injuries \\
\hline 2 & $05-06-2009$ & 1 vehicle hit bicycle & 1 death \\
\hline 3 & $20-06-2010$ & $\begin{array}{l}1 \text { vehicle lost control, } \\
\text { cross to opposite } \\
\text { direction and hit light } \\
\text { pole and } 3 \text { vehicles }\end{array}$ & 1 death 4 injuries \\
\hline 4 & $31-12-2010$ & $\begin{array}{l}1 \text { pickup truck lost } \\
\text { control cross to } \\
\text { opposite direction and } \\
\text { hit } 2 \text { vehicle }\end{array}$ & Several injuries \\
\hline 5 & $30-08-2011$ & $\begin{array}{l}1 \text { vehicle lost control, } \\
\text { hit light pole and } \\
\text { rollover }\end{array}$ & 5 injuries \\
\hline 6 & $10-05-2012$ & $\begin{array}{l}1 \text { motorcycle lost } \\
\text { control }\end{array}$ & - \\
\hline 7 & $15-06-2012$ & 1 vehicle lost control & - \\
\hline 8 & $23-11-2012$ & 1 vehicle lost control & 1 injury \\
\hline 9 & $03-09-2013$ & 1 vehicle lost control & 2 injuries \\
\hline
\end{tabular}




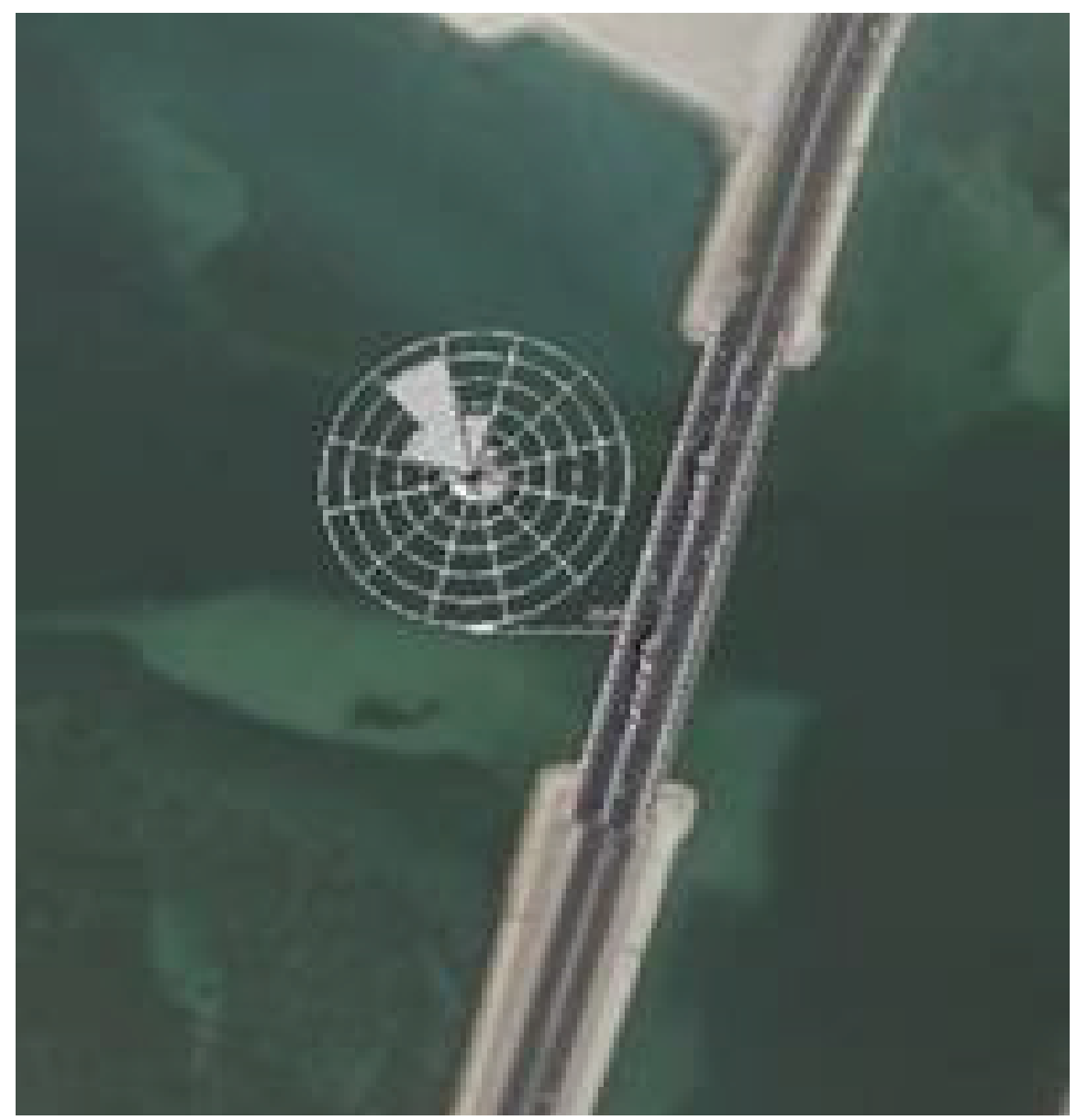

Figure 2: Wind rose attached on Google Earth satellite picture, Al Buflasa et al (2008).

\section{Work Objective}

When vehicles are running on the causeway in a windy condition, side wind disturbance will affect them as environmental disturbances, which may result in directional instability, thus it is important to study the stability of vehicles in such conditions. The work scope in this article, is to investigate the aerodynamic forces affecting vehicle crossing the bridge for different scenarios, although the scope of the study extend beyond this work to analyze the effect of the aerodynamic forces on vehicle stability.

\section{Coordinate System and Geometry}

Figure 3 shows the coordinate system and problem setup used in the present investigation.

The vehicle model used in this study is an identical to the 2 - $d$ experimental model used by Sims-Williams (2001). This model is also used by Corin, He, and Dominy (2008) 


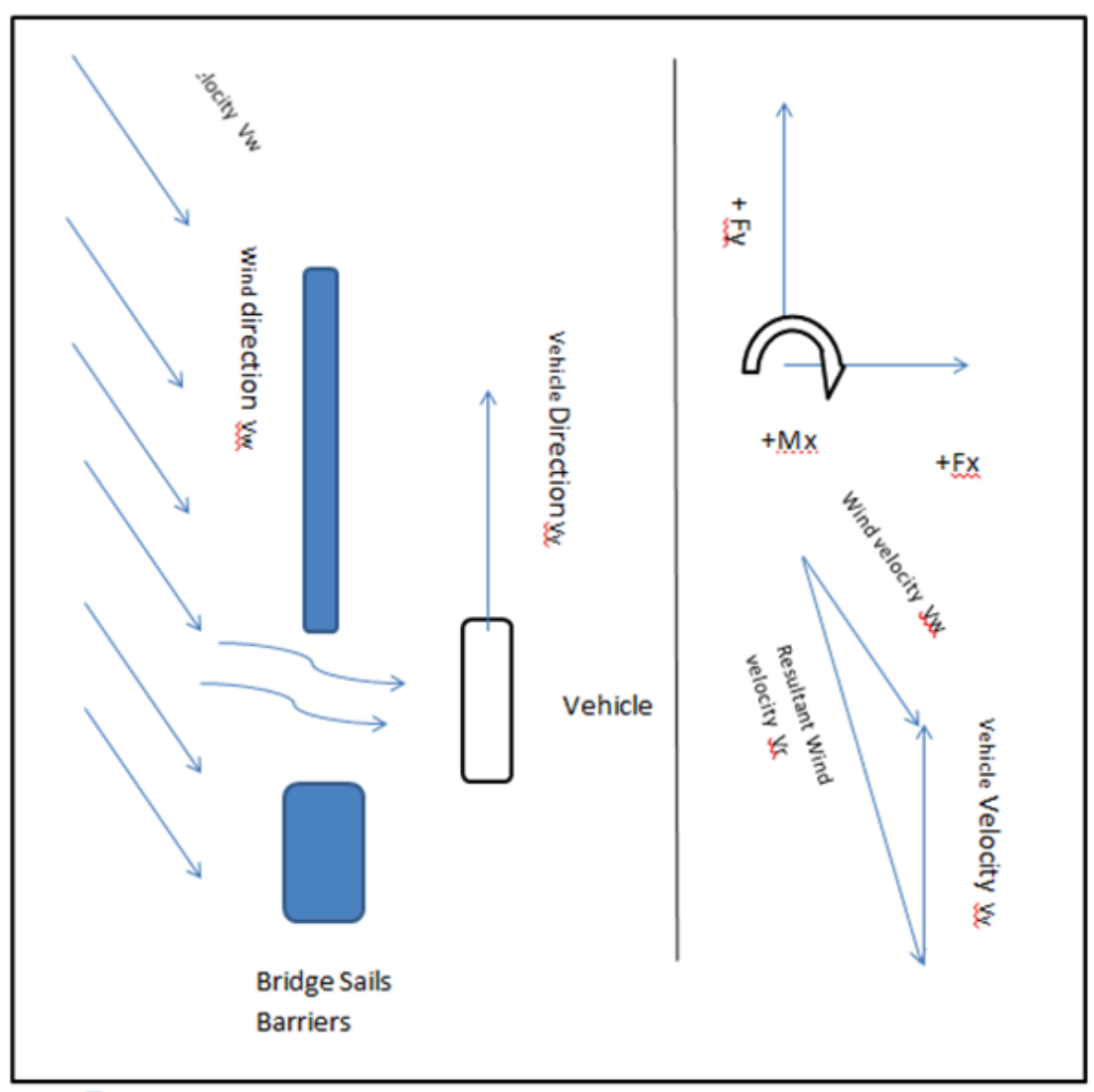

Figure 3: Coordinate system and problem setup.

for their CFD investigation. Table 2 shows the dimensions used for a full-scale vehicle geometry.

TABLE 3: Vehicle and Bridge dimensions.

\begin{tabular}{|l|c|c|c|}
\hline Geometry & Length & Width & Corner \\
\hline Vehicle & $5.57 \mathrm{~m}$ & $1.323 \mathrm{~m}$ & Radius $0.55 \mathrm{~m}$ \\
\hline Bridge sails & $24.5 \mathrm{~m}$ & $0.6 \mathrm{~m}$ & Right angle \\
\hline Bridge column & $4 \mathrm{~m}$ & $1.5 \mathrm{~m}$ & Right angle \\
\hline
\end{tabular}

\section{Computational Simulation Approach}

Computer simulations were conducted using CFD code Fluent Ansys ${ }^{\circledR}$ 14. 2-d models. Experimental and computational work available in the literature was used for validation.

\subsection{Computational simulation procedure}




\subsubsection{Single vehicle model geometry validation}

The vehicle model used is an identical to the 2- $d$ experimental model used by SimsWilliams (2001) and is also used by Corin, He, and Dominy (2008) in their CFD investigation. The mesh design, boundary conditions and coefficient of pressure Cp adapted in our validation are exactly the same which were used by Corin, He, and Dominy (2008).

\subsubsection{Simulation validation of the unsteady solver}

The simulation of vehicle overtaking maneuver conducted by Corin, is reproduced here for validation. He, and Dominy (2008) CFD used Fluent Ansys ${ }^{\circledR}$ ability of translational sliding mesh in their simulation. The parameters used in validation are $\mathrm{Cd}$ and pressure fields for the overtaking maneuver were: wind yaw angle of -20 degree of PARAD2 model and relative velocity $\mathrm{V} r=13.4 \mathrm{~m} / \mathrm{s}$.

\subsubsection{Procedures of aerodynamic parameters investigation}

A 2-d finite element model was built using an actual bridge dimensions and assumed vehicle dimensions like those used by Corin, He, and Dominy (2008), a sliding mesh technique is used at defined vehicle dimension and wind velocities.

\subsection{Model simulation procedure}

\subsubsection{Model layout}

The model layout consists of three zones namely; bridge, vehicle and after vehicle zone. Zone models are generated byusing Solidworks ${ }^{\circledR}$ separately, and are saved in STEP format file before uploading it to Fluent ${ }^{\circledR}$ Geometry Modeler ${ }^{\circledR}$, see Figure 3.

The dimensions and outer boundary conditions of the three zones are listed in table 3. The size of the computational domain was set as the real road lanes width and the sails (side walls) length at the beginning and after running the simulation an additional length is needed to capture the changes in the flow in the entrance and exit of the bridge. Sufficient distances added between the vehicle and sails that extend the boundary in length. 


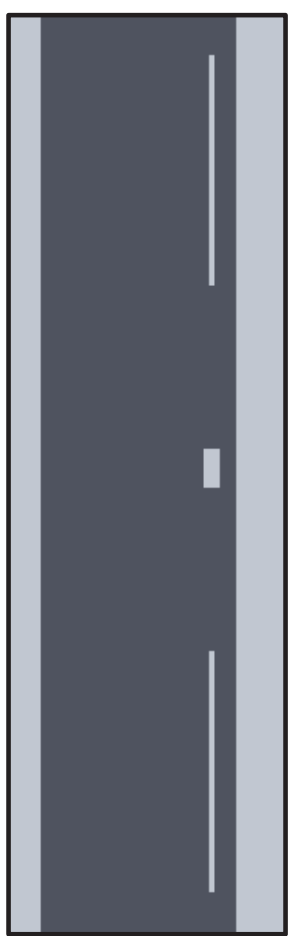

(a)

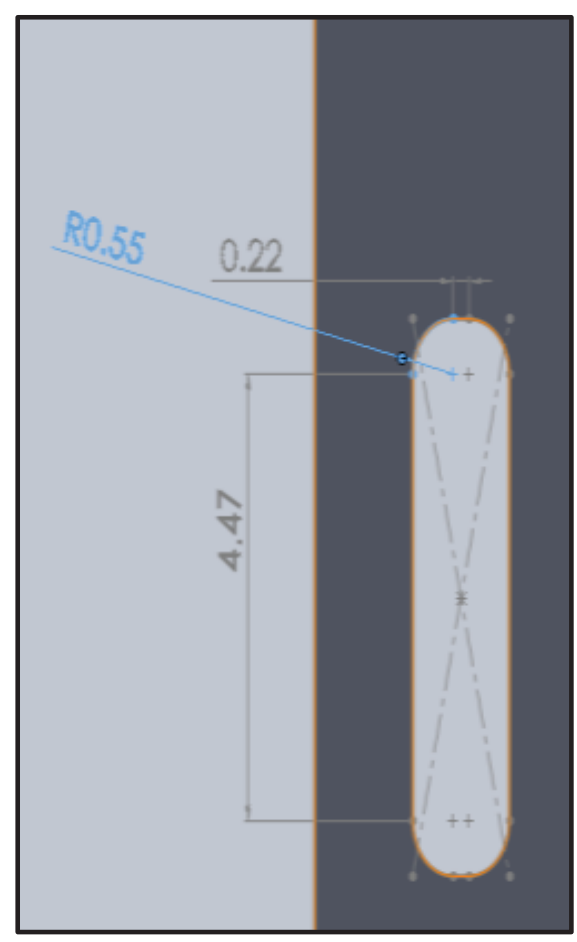

(b)

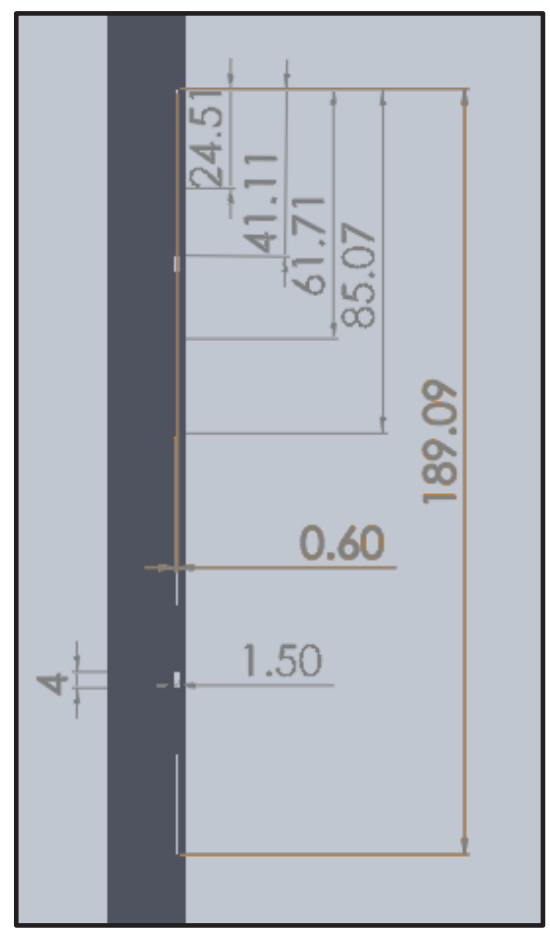

(c)

Figure 4: (a) Bridge zone, (b) Bridge zone dimensions, and (c) Vehicle zone in 2-d generated by SolidWorks ${ }^{\circledR}$.

TABLE 4: Dimensions of the three zones.

Zones
First zone
Second zone
Third zone

Represent
Bridge sail barrier
Vehicle in the first lane
After Vehicle

\begin{tabular}{|c|}
\hline Width (m) \\
\hline 19.5 \\
12 \\
12 \\
\hline
\end{tabular}

\begin{tabular}{|c|}
\hline Length (m) \\
\hline 344 \\
\hline 1046 \\
\hline 344 \\
\hline
\end{tabular}

The three zones are imported to Fluent Ansys ${ }^{\circledR}$ Design Modeller, each zone in separated process to prevent merging. Zones and outer boundary are given names in order to help the program suggest suitable boundary conditions.

\subsubsection{Meshing design}

The computational mesh design was Multi-block structured meshes with 8 mesh blocks for bridge zone, 6 blocks for vehicle zone and 2 blocks for after vehicle zone, and multi block was used to control the meshing process easily. Enlargement ratios used between 1.2 and 1.3 to give appropriate mesh expansion. The number of nodes on the vehicle surface are 250 , and number of mesh cells in the computational domain are 198607 mesh cells, see Figure 5 . 


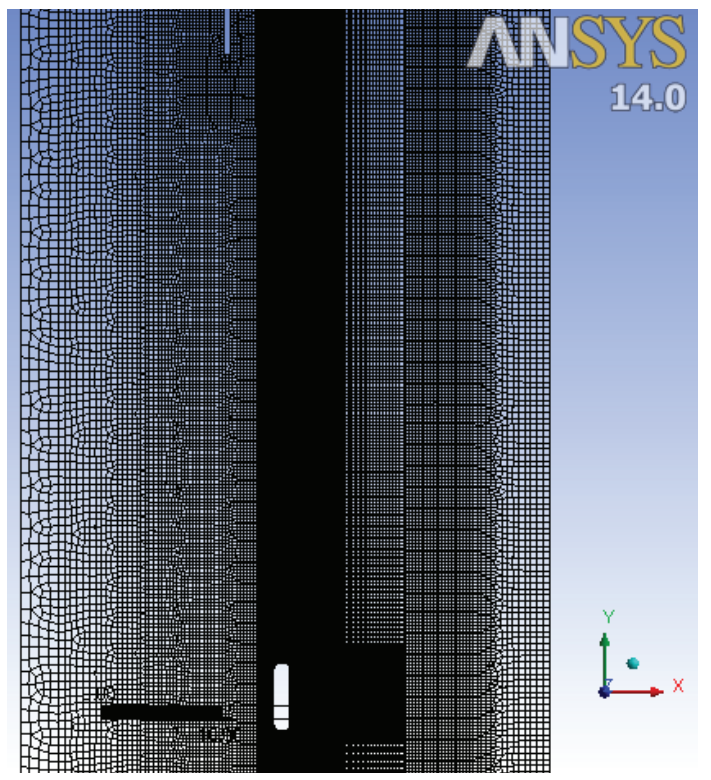

(a)

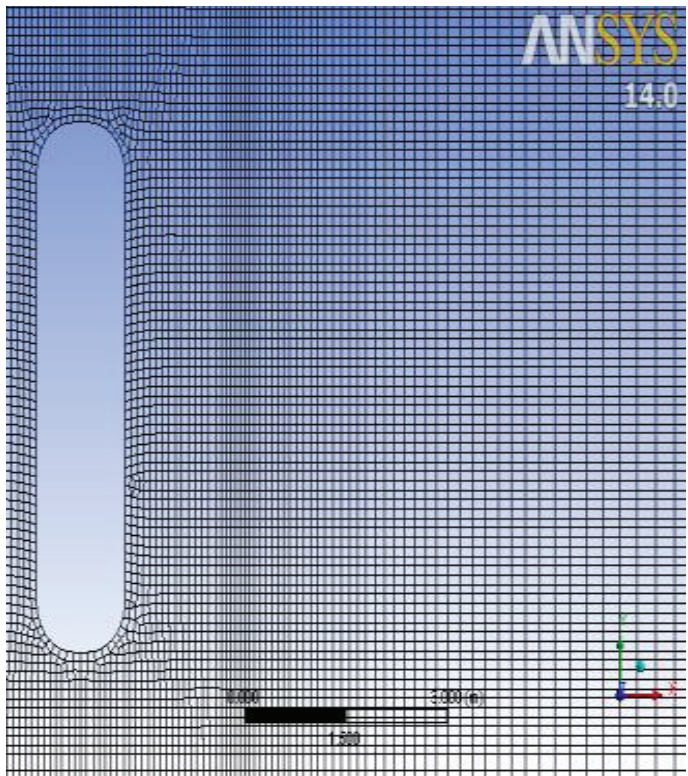

(b)

Figure 5: (a) Part of the domain mesh, and (b) Vehicle zoomed mesh.

\subsubsection{Boundary conditions}

The outer boundaries of the computational domain were either flow inlet or pressure outlet depending on the flow direction where flow speed and direction were set. At the boundaries between zones interface boundary where set to interchange the information while mesh slide. The boundary conditions of the three zones geometry are listed in Table 4 . Velocity inlet (velocity of crosswind) has different values and directions in the simulation.

To investigate the effect of different wind direction (angle of attack), verity of crosswind direction $\left(45^{\circ}, 60^{\circ}\right.$ and $\left.90^{\circ}\right)$ at speed of $30 \mathrm{~m} / \mathrm{s}$ were tested. And to investigate the effect of different wind speeds, verity of crosswind velocities of 20 and $30 \mathrm{~m} / \mathrm{s}$ at $90^{\circ}$ angle are tested. To investigate the effect of vehicle velocity, $22.22 \mathrm{~m} / \mathrm{s}, 27 \mathrm{~m} / \mathrm{s}$ and $33.33 \mathrm{~m} / \mathrm{s}$ velocities were tested. A list of the test conditions are shown in table 5 .

\subsubsection{Solution method and time step}

Pressure-based transient with planner solver were set, a viscous model with standard $K-\varepsilon$ and standard wall functions used, flow volume set as air.

Bridge zone and after zone were set with no frame motion nor mesh motion, vehicle zone translational sliding mesh and frame with different velocities $(22.22 \mathrm{~m} / \mathrm{s}, 27$ 
TABLE 5: The domain zones and geometry boundary conditions.

Geometry
Bridge sails and columns
Top and left boundary
Bottom boundary
Right boundary
Vehicle
Left boundary
Right boundary
Top boundary
Bottom boundary
Left boundary
Right and bottom
boundary
Top boundary
Other

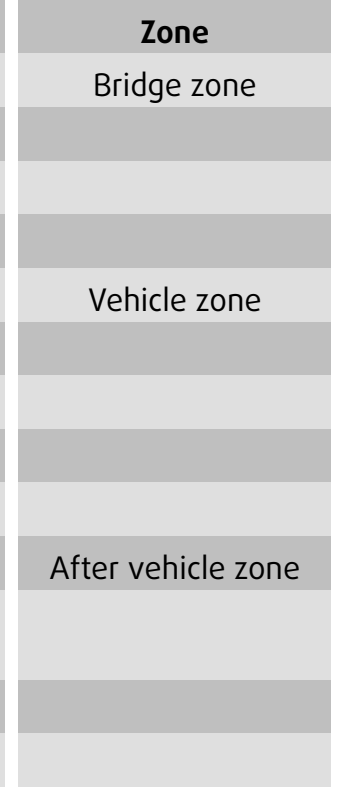

TABLE 6: List of Vehicle velocity and wind speed and direction tested.

Vehicle velocity
$97.2 \mathrm{~km} / \mathrm{hr} .(27 \mathrm{~m} / \mathrm{s})$
$80 \mathrm{~km} / \mathrm{hr} .(22.22 \mathrm{~m} / \mathrm{s})$
$120 \mathrm{~km} / \mathrm{hr} .(33.33 \mathrm{~m} / \mathrm{s})$

\begin{tabular}{c}
$\begin{array}{c}\text { Wind speed } \\
(\mathrm{m} / \mathrm{s})\end{array}$ \\
20 \\
30 \\
30 \\
30 \\
\hline
\end{tabular}

Wind direction
$90^{\circ}$
$\begin{gathered}45^{\circ}, 60^{\circ} \text { and } 90^{\circ} \\ 90^{\circ} \\ 90^{\circ}\end{gathered}$

$\mathrm{m} / \mathrm{s}$ and 33.33) toward positive $y$-axis. Reference values used are air density $(\rho)=$ $1.225\left(\mathrm{~kg} / \mathrm{m}^{3}\right)$, dynamic viscosity $(\mu)=1.7894 \mathrm{e}-5(\mathrm{~kg} / \mathrm{m}-\mathrm{s})$, Area $=1\left(\mathrm{~m}^{2}\right)$, depth=1 $(\mathrm{m})$, vehicle length $=5.57(\mathrm{~m})$, Pressure $=101(\mathrm{kPa})$, and Temperature $=288.16(\mathrm{k})$. Area set as a unity because the dependency of area in drag and side force calculation by the software, the values are adjusted later. Total time was 11.52 (s), a time step of 0.016, 0.032 , and 0.064 (s) were tested. The time step 0.032 (s) is found to give adequate compromise between solution accuracy to allow the results to converge in 20 iterations per time step.

\section{Simulation Results}

\subsection{Model validation results}




\subsubsection{Single vehicle model geometry validation results}

Similar simulation to Corin, $\mathrm{He}$, and Dominy (2008) for isolated vehicle model is conducted. Experimental and computational pressure coefficients (CP) along PARAD1 model shown in Figure 6, is compared to Figure 40 by Corin, He, and Dominy (2008) which includes experimental and CFD results for the same PARAD1 model. The comparisons show similarity in results validating the vehicle geometry used.

\subsubsection{Validation of the unsteady solver}

Figure 7 shows the $\mathrm{Cd}$ comparison between our simulation results and the results from Corin, He, and Dominy (2008). At relative velocity $\mathrm{V} r=13.4 \mathrm{~m} / \mathrm{s}$ also Pressure contour of the two vehicles while takeover replicated simulation is presented and compared in fig. 8. Both Cd results and pressure contours show similarity which validates the unsteady solver.

\subsection{Aerodynamic model simulation results and discussion}

\subsubsection{Effect of time steps}

To find the effect of time steps a model tested for up to $30 \mathrm{~m} / \mathrm{s}$ cross wind at 90 degree with (180, 360, 720 time steps) and step size of (0.064, 0.032, and $0.016(\mathrm{~s}))$, where total time is $11.52(\mathrm{~s})$, where smaller time step gives more precise results, but it takes more time to complete the computational task. Comparing results of side force in Figure 9 and drag in Figure 10, show higher oscillatory behavior in the 720 steps results, while we get smother curve in the 180 steps results, and 360 steps in between. Values are almost same for all step sizes in side force, while drag force shows more differences, noticing that side force are 10 times higher than drag forces.

\subsubsection{Wind velocity contour across the bridge}

Figure 11 shows the cross wind velocity contours and its direction change through bridge, the upstream velocity is $27 \mathrm{~m} / \mathrm{s}$, where it is reaching $98 \mathrm{~m} / \mathrm{s}$ in the mid open, zero directly behind the sails and negative after the sails showing some vortices.

Similar results of wind velocity variation are shown in Figure 12 , where $x$-direction velocity in the first lane after the sails directly found less value in peaks and more 


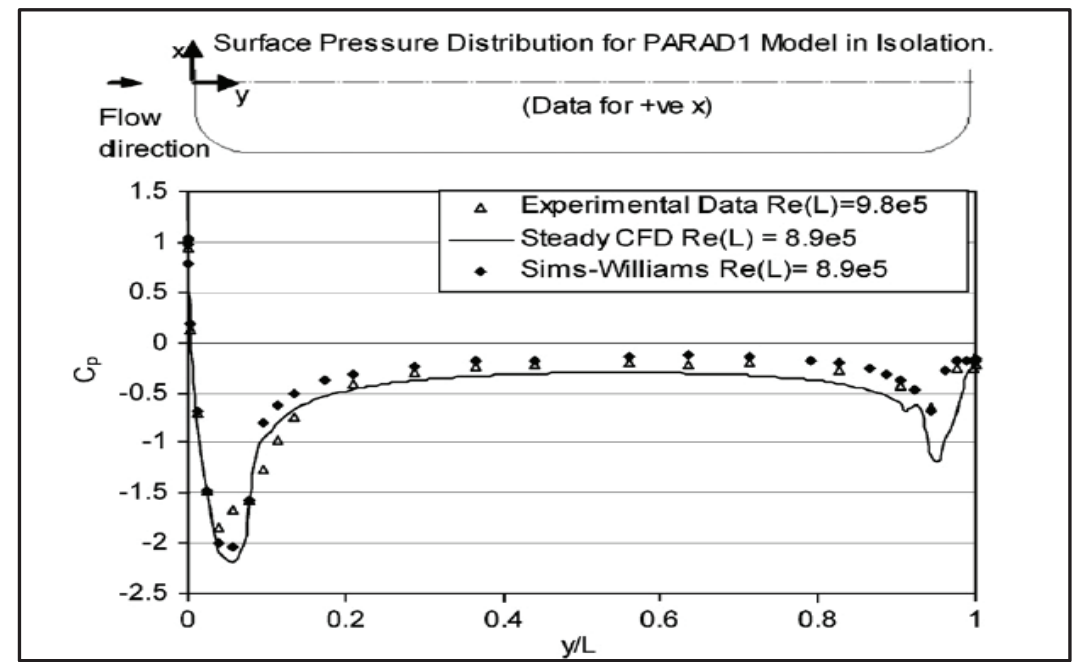

(a)

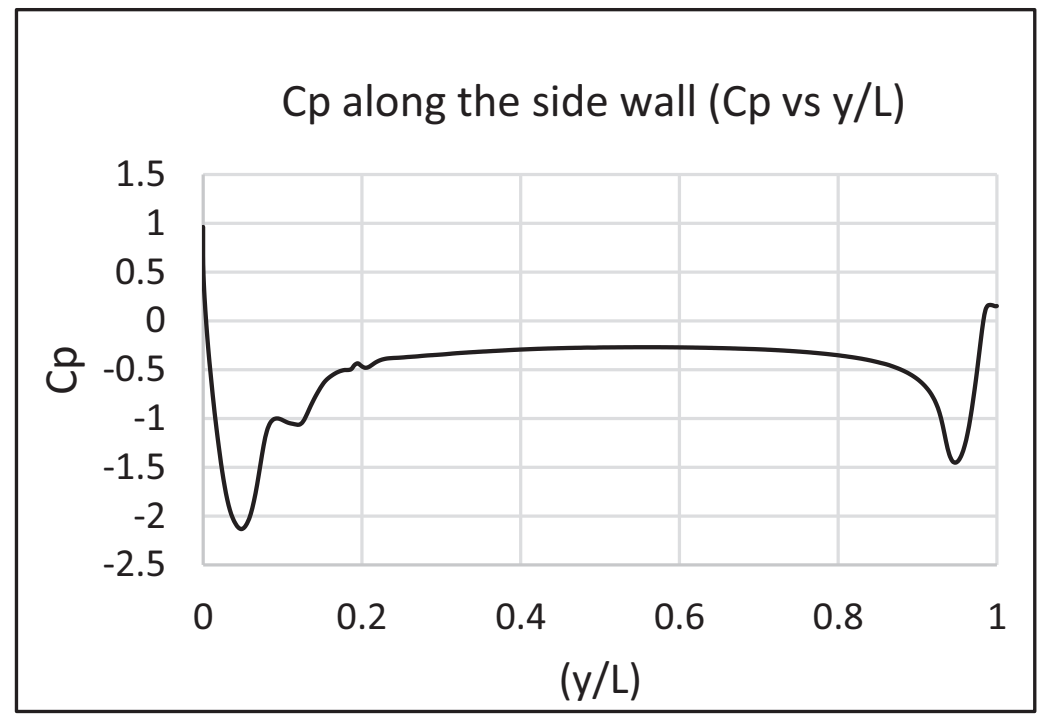

(b)

Figure 6: Pressure distribution for PARAD1 results. (a) Experimental and CFD after Corin, He, and Dominy (2008) and (b) the present work.

variant in value, whereas after the lanes the velocity is more in peaks and less variant. A negative pulse due the column between the sails can be observed.

\subsubsection{Effect of wind velocity}

The effect of wind velocities on the side force is shown in figures 13 and 14 . The wind velocities $V w=20 \mathrm{~m} / \mathrm{s}$ and $30 \mathrm{~m} / \mathrm{s}$ are applied at 90 degrees while the vehicle is 


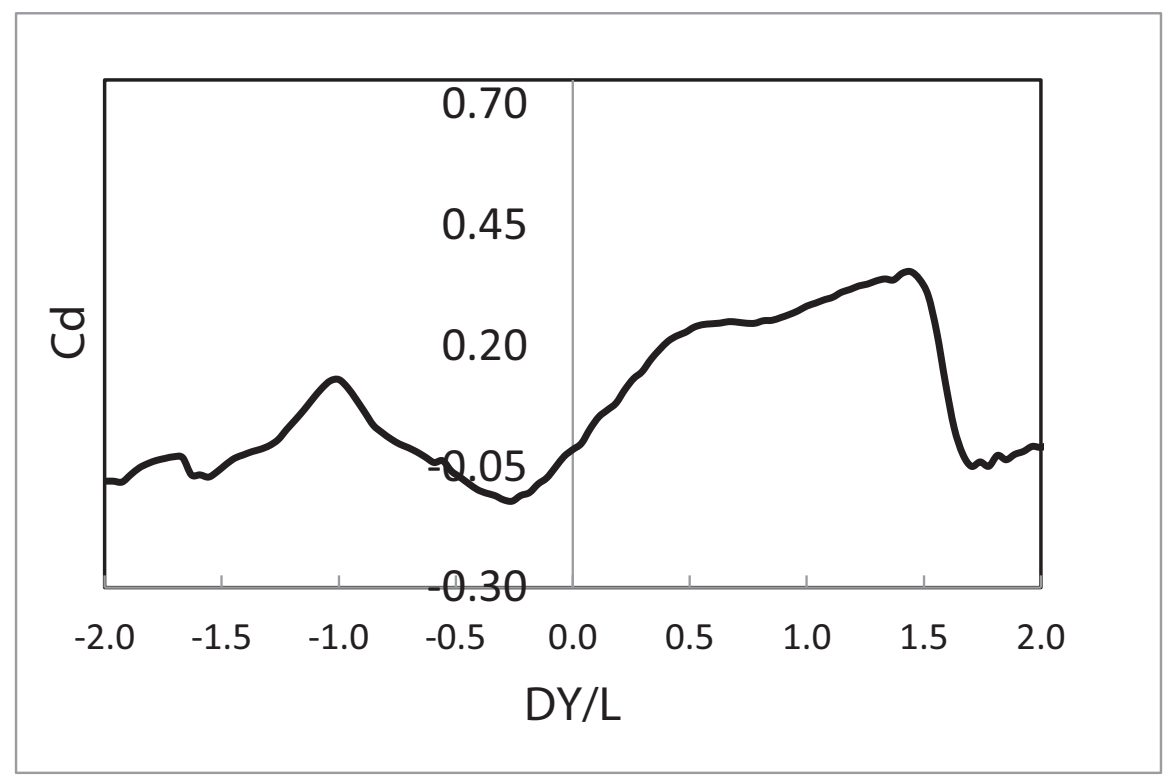

(a)

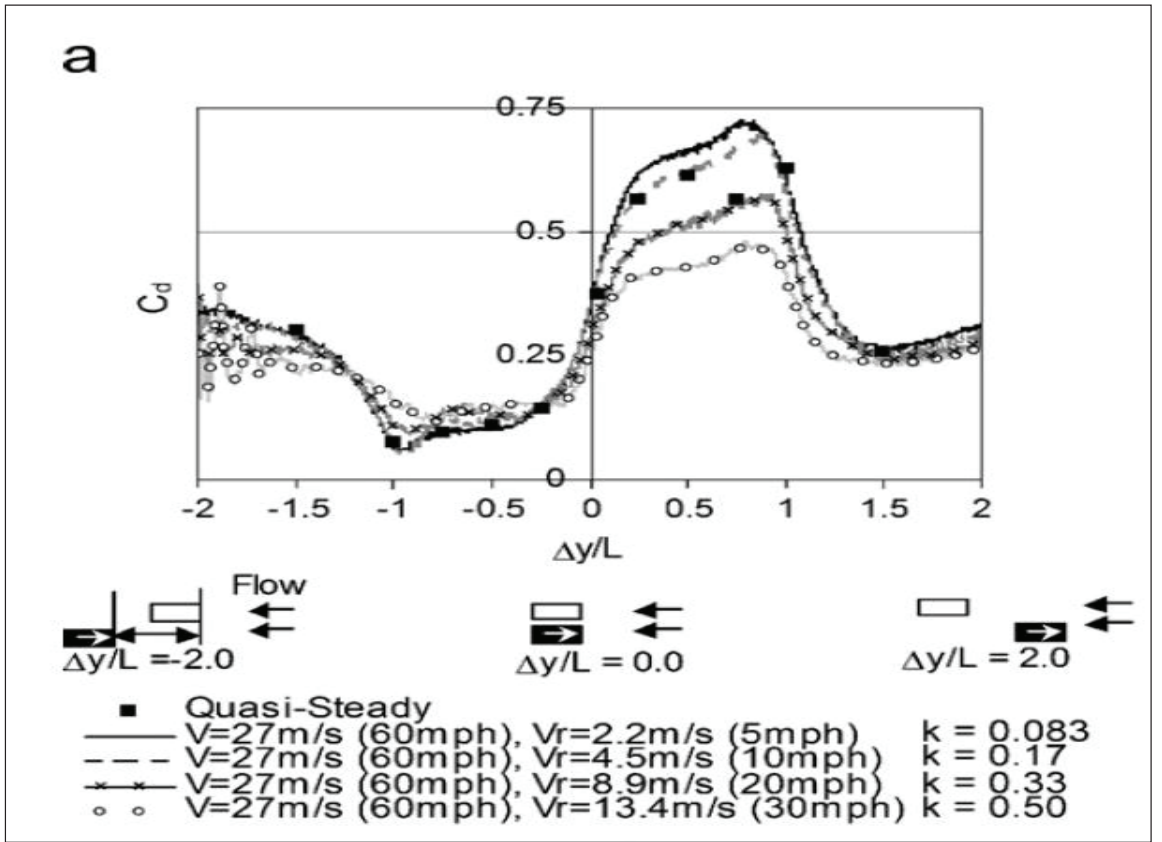

(b)

Figure 7: Sliding mesh results of $\mathrm{Cd}$ vs $\Delta \mathrm{Y} / \mathrm{L}$ at $\mathrm{Vr} 13.4 \mathrm{~m} / \mathrm{s}$, from a) present work simulation results, b) Corin, He, and Dominy (2008).

moving with a forward speed $V v=27 \mathrm{~m} / \mathrm{s}$. From these two figures the side force is increased with the increase of wind speed. 


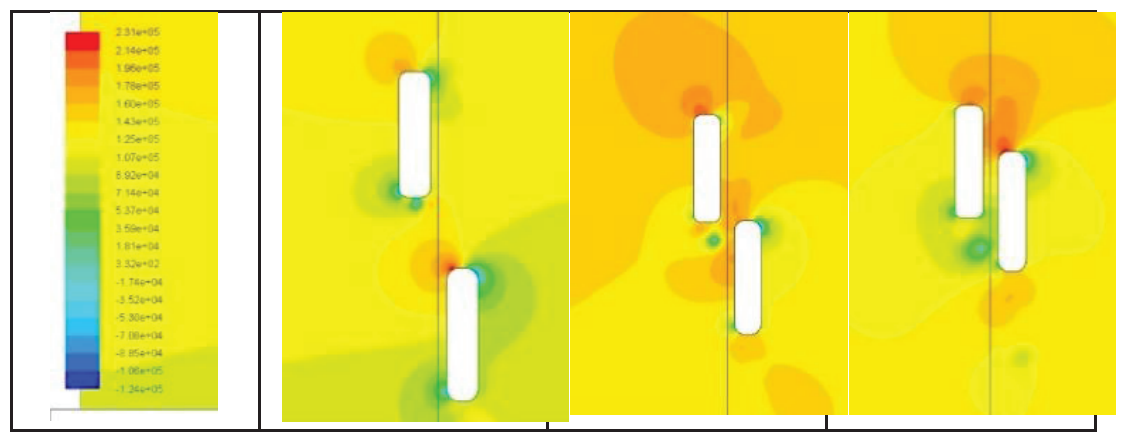

(a)

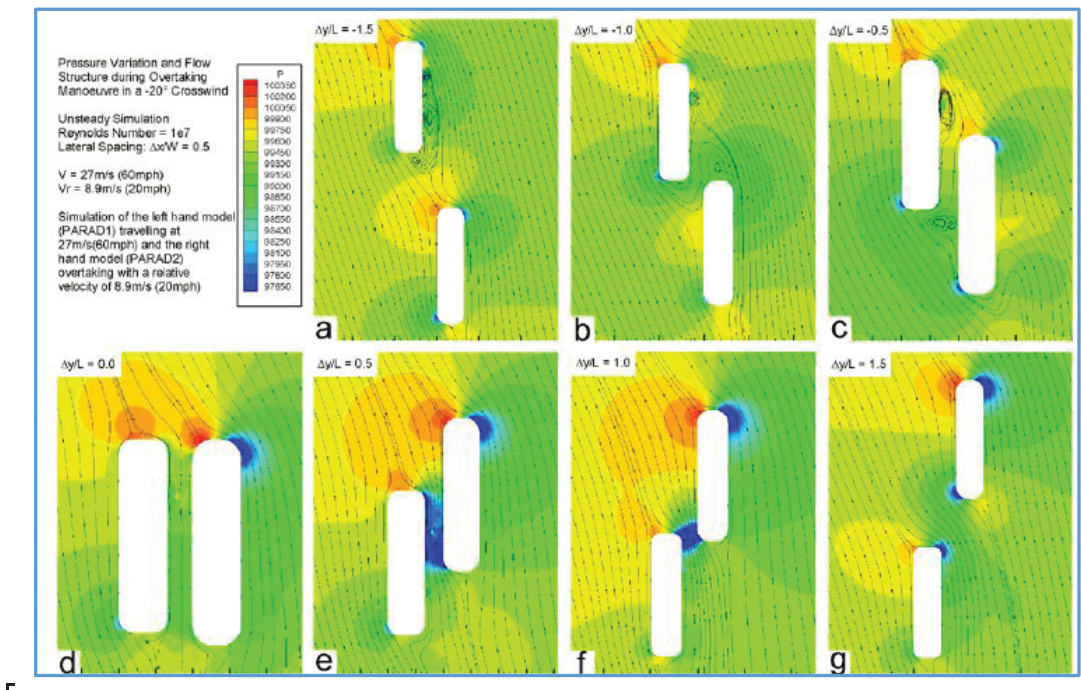

[ Fig. 10. Pressure fields and flow streamlines for the UNSTEADY analysis of overtaking manoeuvre in a $\beta=-20^{\circ}$ yaw crosswind.

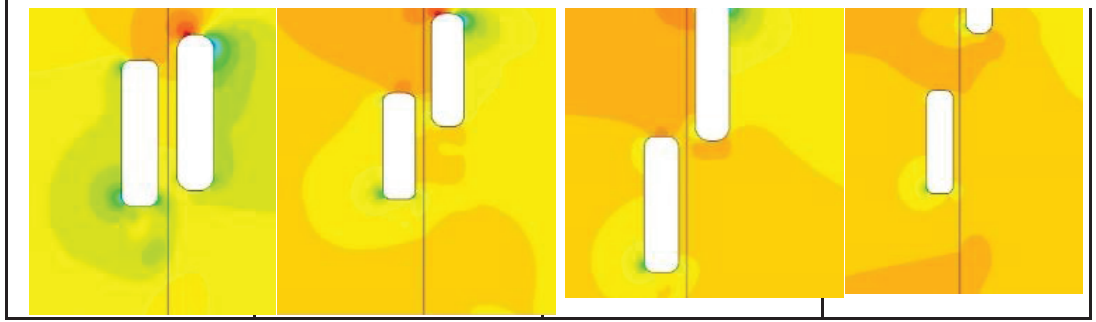

(b)

Figure 8: Pressure fields for overtaking maneuver in yaw angle $=-20$ degree, $(41 \mathrm{a})$ replicated simulation, and ( $41 \mathrm{~b}$ ) from Corin, He, and Dominy (2008).

\subsubsection{Effect of wind attack angle}

Cross wind at $30 \mathrm{~m} / \mathrm{s}$, with attack angle 45,60 , and 90 degrees were tested at vehicle forward velocity $V v=30 \mathrm{~m} / \mathrm{s}$. The effect of attack angle on wind velocity profile is clear in Figure 15. The wind velocity, the vehicle yaw moment and the side force are directly proportional to the wind attack angle as shown in Figs. 15-16. 


\section{Effec of no. of Time steps on (Fs) Side force results}

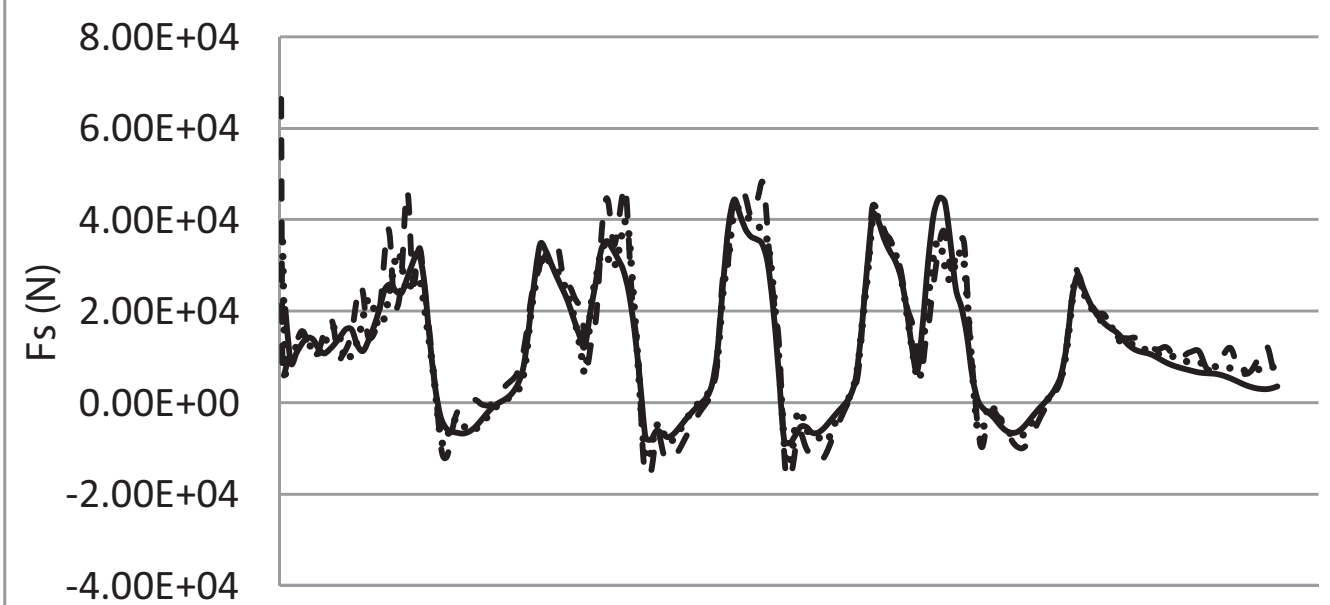

0.00E+00 2.00E+00 4.00E+00 6.00E+00 8.00E+00 1.00E+01 1.20E+01 Time (s)

Fs 180

Fs $360 \quad$ - - - Fs 720

Figure 9: Effect of no. of Time steps on side force results, Vv=27m/s, Vw=30m/s.

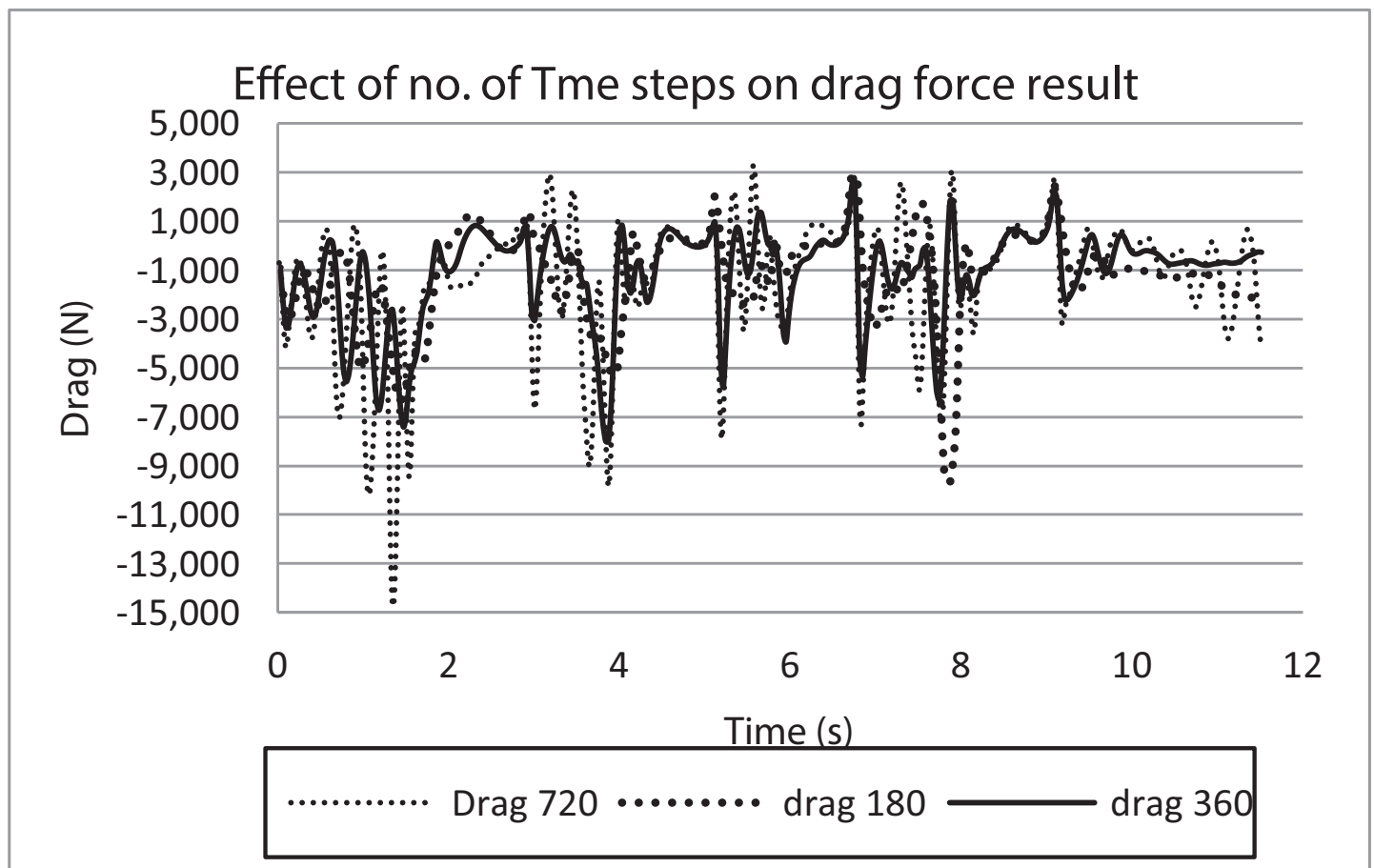

Figure 10: Effect of no. of Time steps on drag force results, Vv=27m/s, Vw=30m/s.

\subsubsection{Sample results}

Results of vehicle velocity $V v=27 \mathrm{~m} / \mathrm{s}$, cross wind velocity $V w=30 \mathrm{~m} / \mathrm{s}$ at $90^{\circ}$ angle of wind, are presented. Dimensionless coefficients $(C d, C s$ and $C m)$ results are shown 


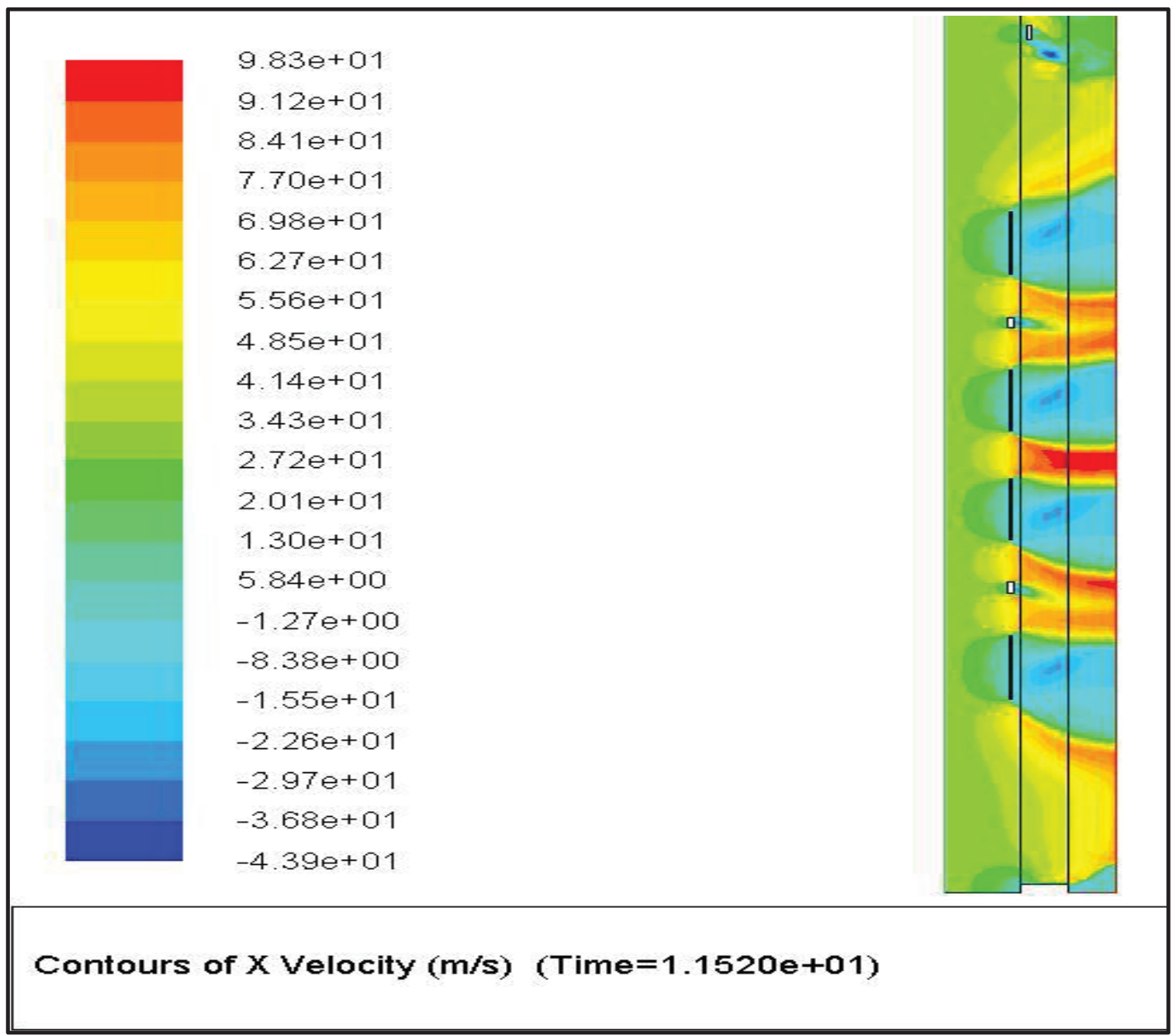

Figure 11: Velocity contours of wind in $x$ direction (side wind) crossing the bridge with $V w=30 m / s$.

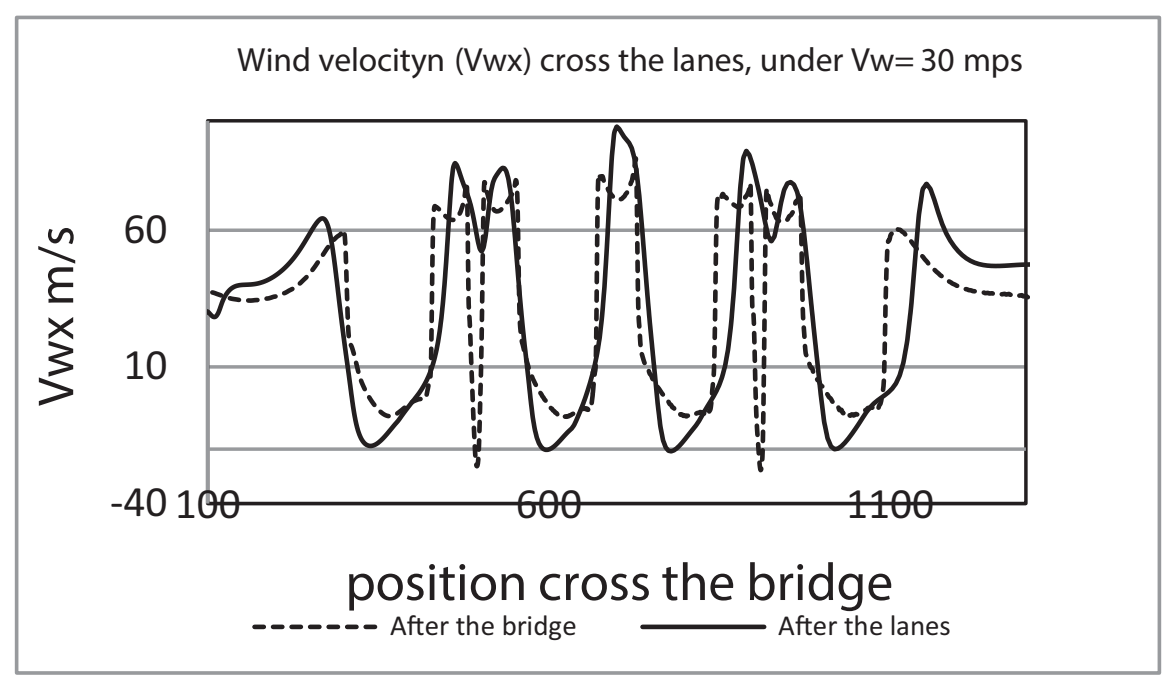

Figure 12: Side wind velocity versus vehicle position.

in Figure 18. Forces and moments are calculated using coefficients obtained from the results shown in figure 19. 


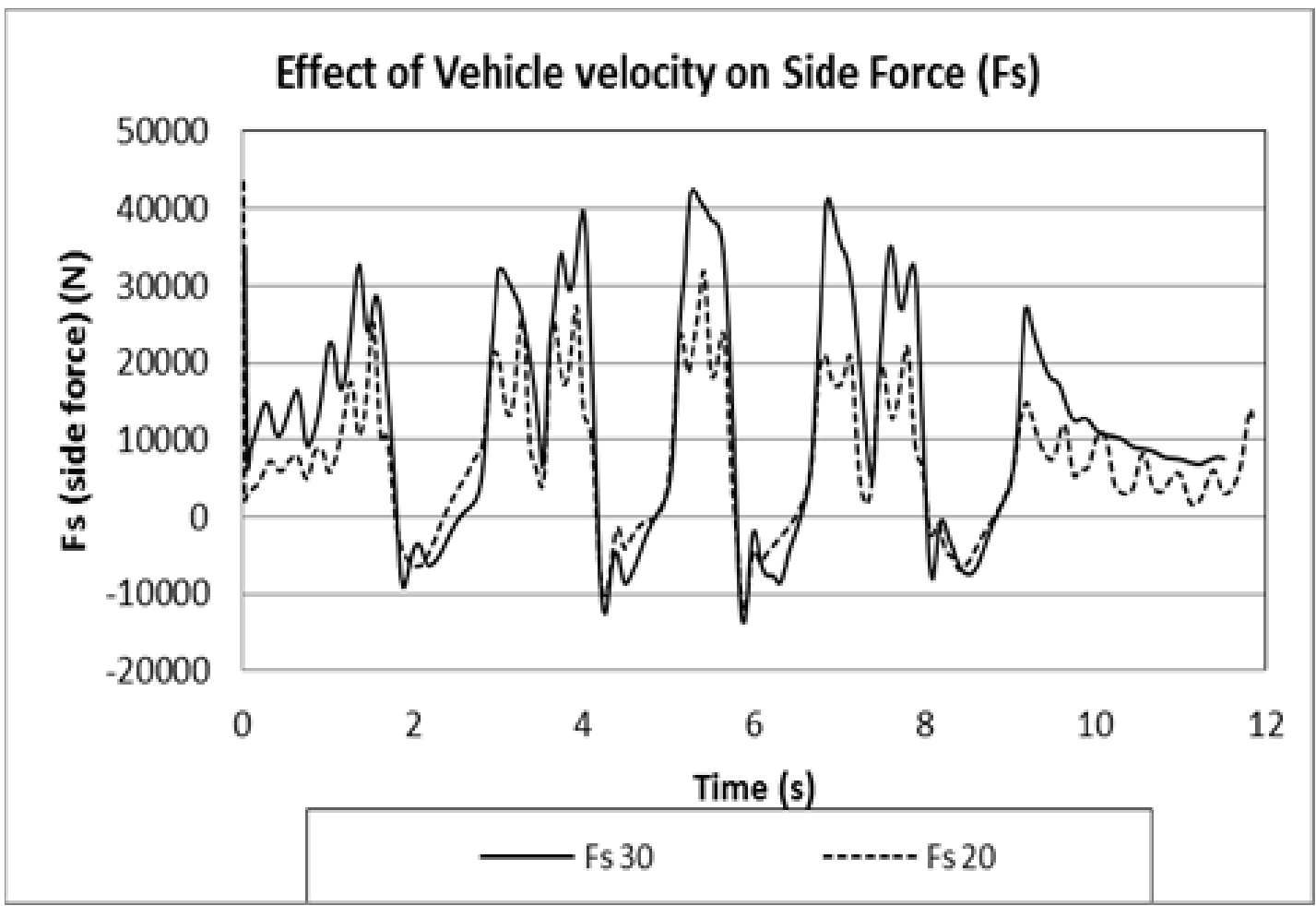

Figure 13: Effect of wind velocity on side force at $V v=27 \mathrm{~m} / \mathrm{s}$.

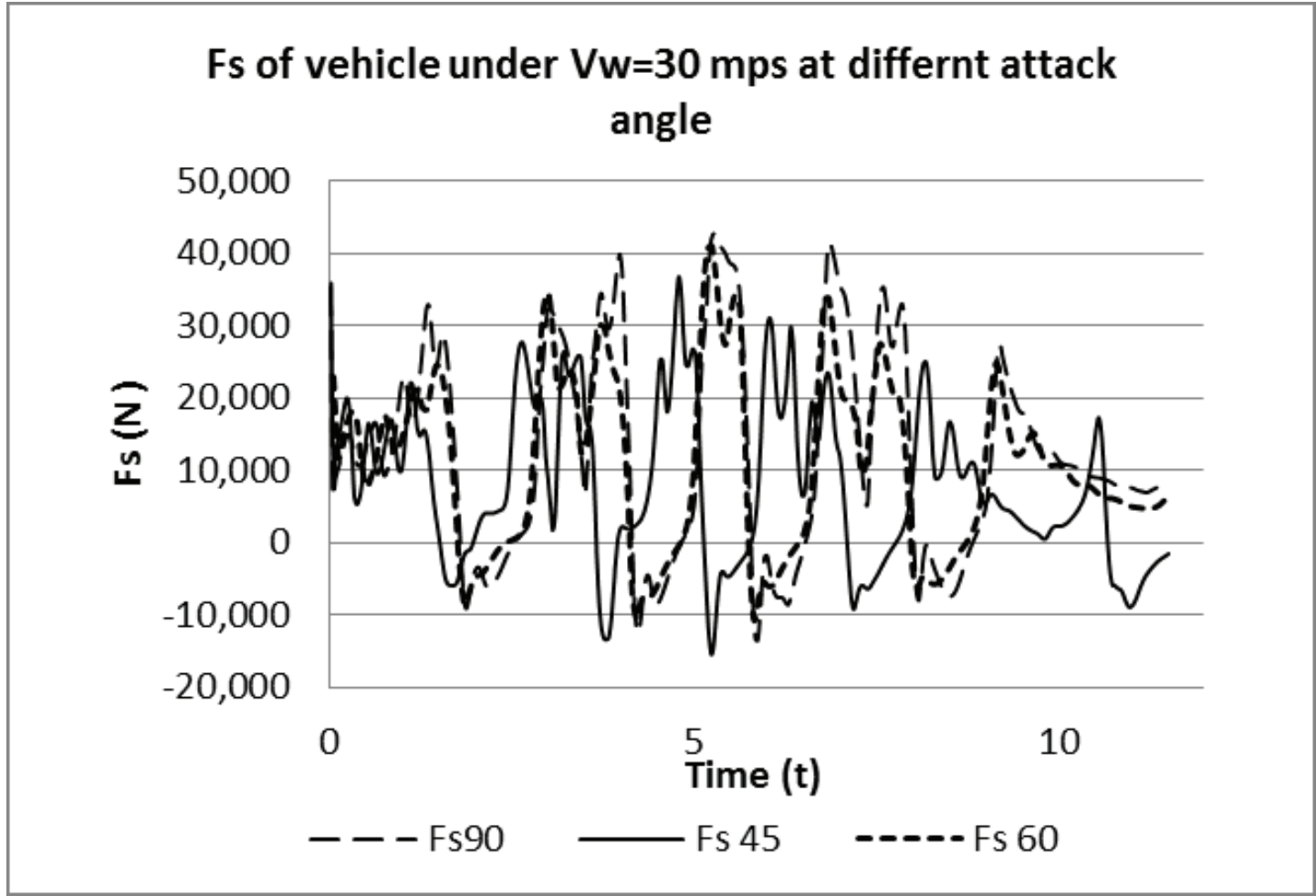

Figure 14: Effect of wind velocity on yaw moment at vehicle forward velocity $V v=27 \mathrm{~m} / \mathrm{s}$. 


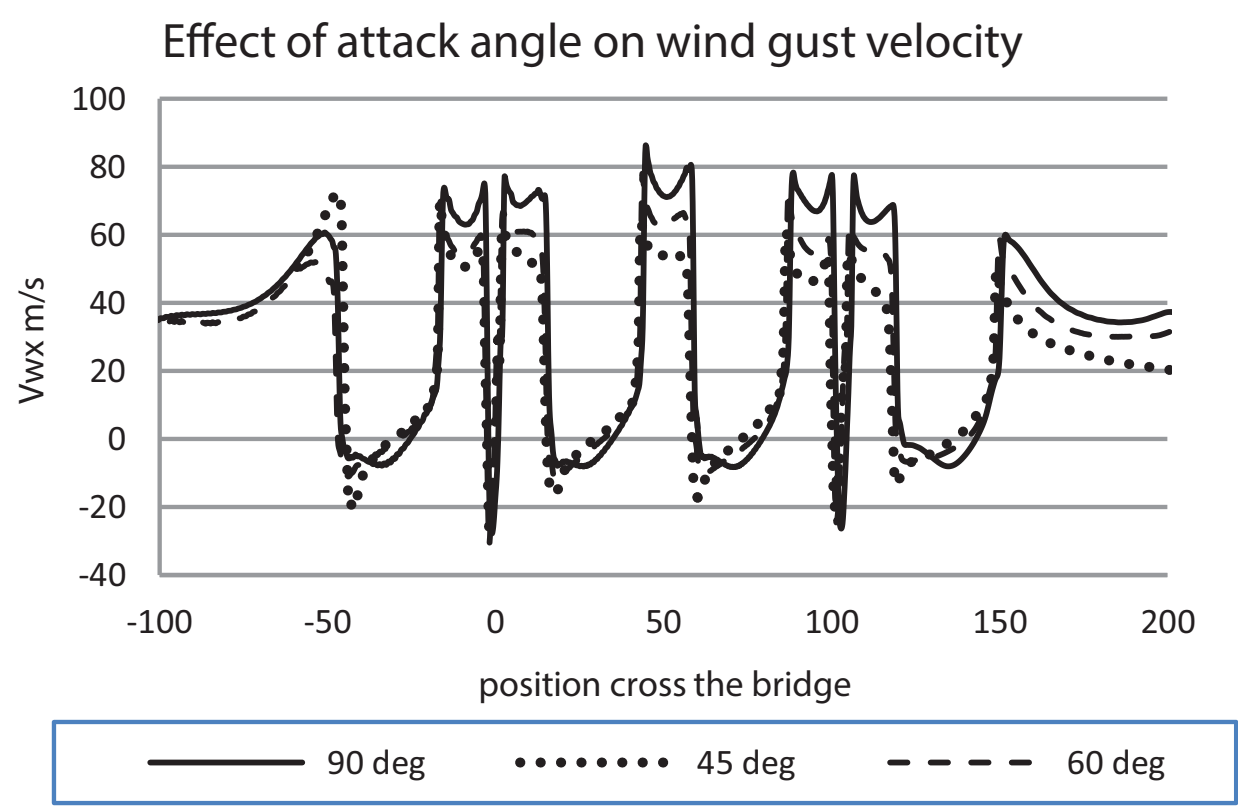

Figure 15: Effect of attack angle on wind gust velocity after the sails (at $V w=30 \mathrm{~m} / \mathrm{s}, \mathrm{Vv}=27 \mathrm{~m} / \mathrm{s}$ ).

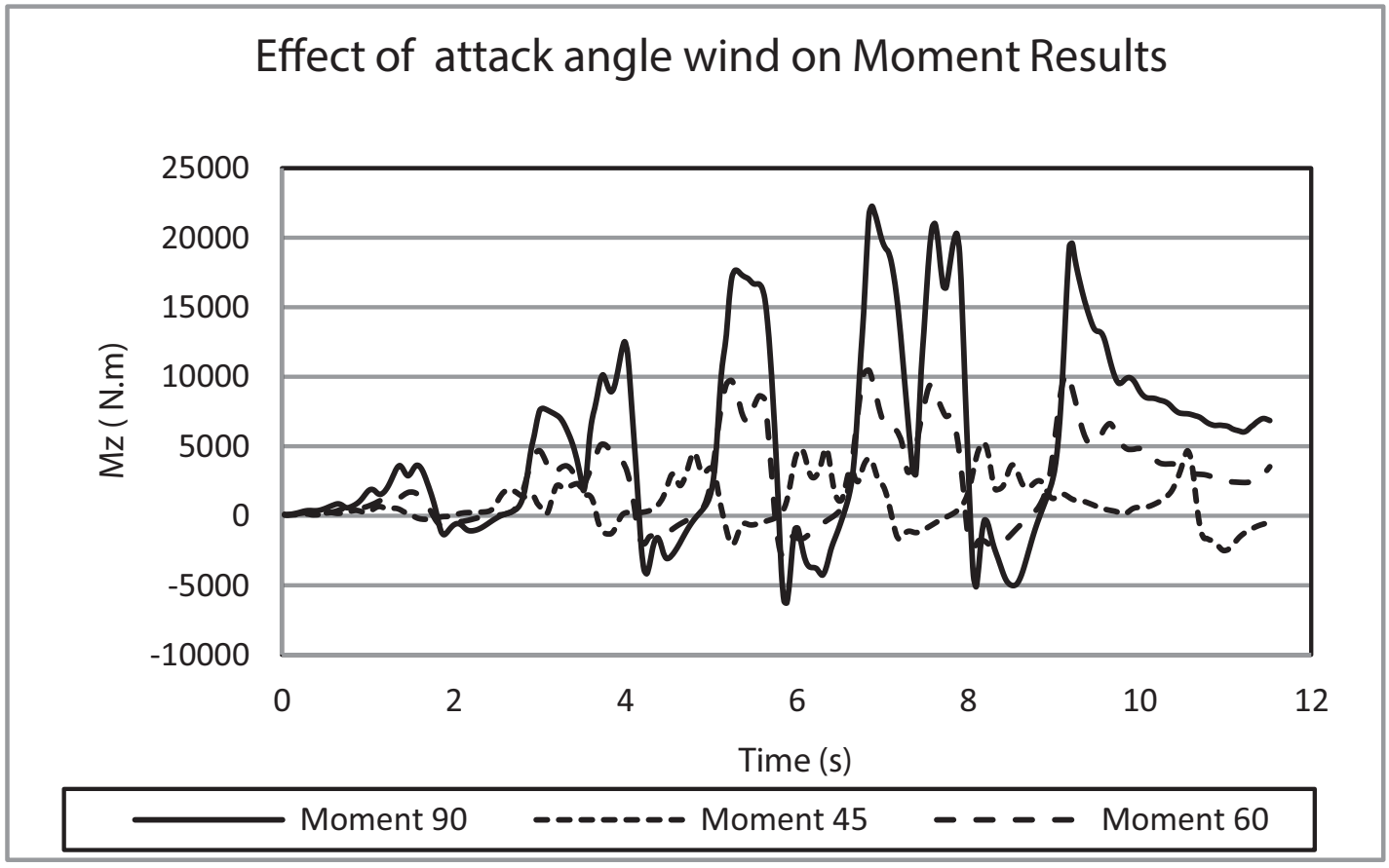

Figure 16: Effect of wind attack angle on vehicle yaw Moment at $V w=30 \mathrm{~m} / \mathrm{s}$ and $V v=27 \mathrm{~m} / \mathrm{s}$. 


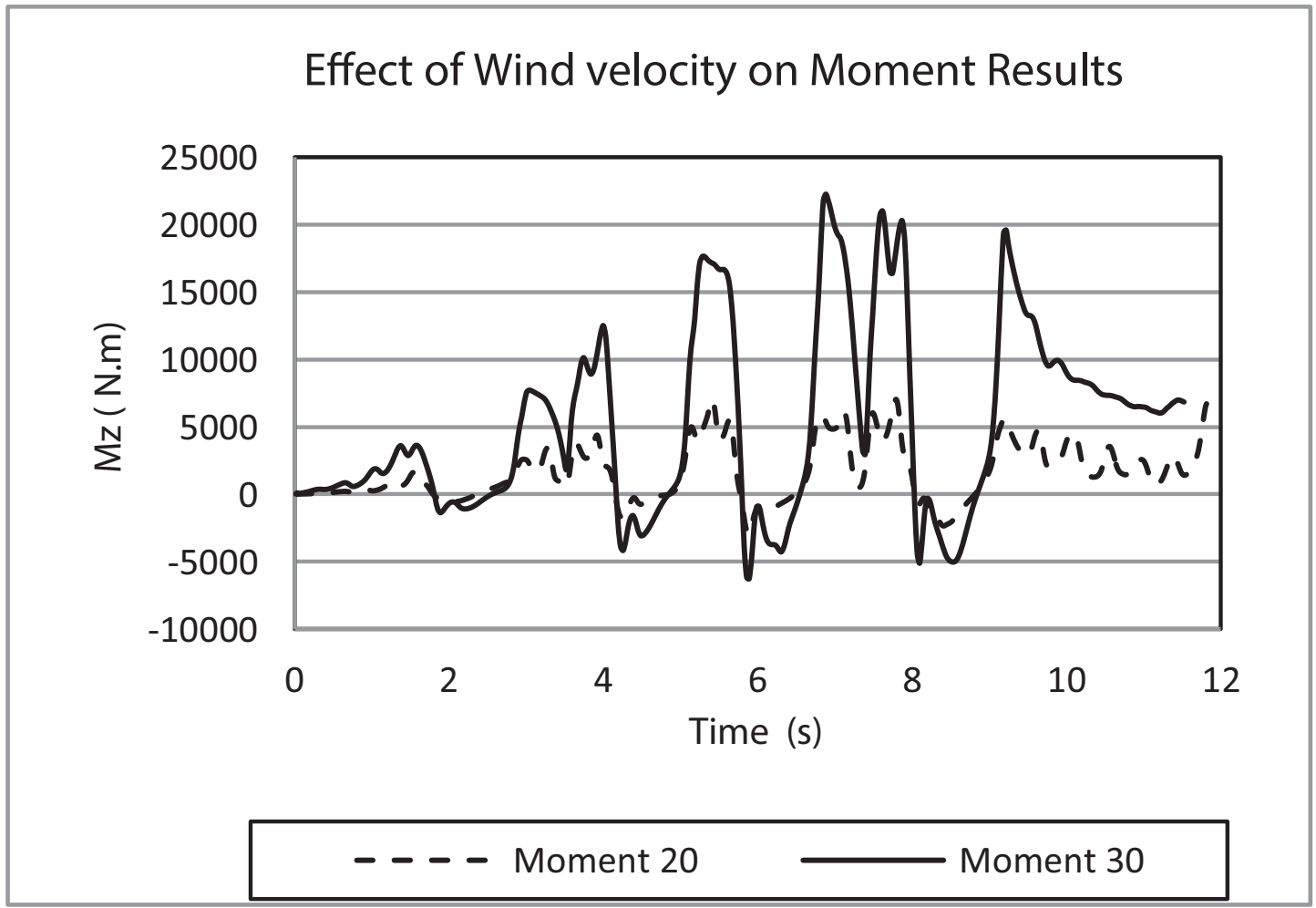

Figure 17: Effect of wind attack angel on Side force (Fs) at $V w=30 \mathrm{~m} / \mathrm{s}$ and $V v=27 \mathrm{~m} / \mathrm{s}$.

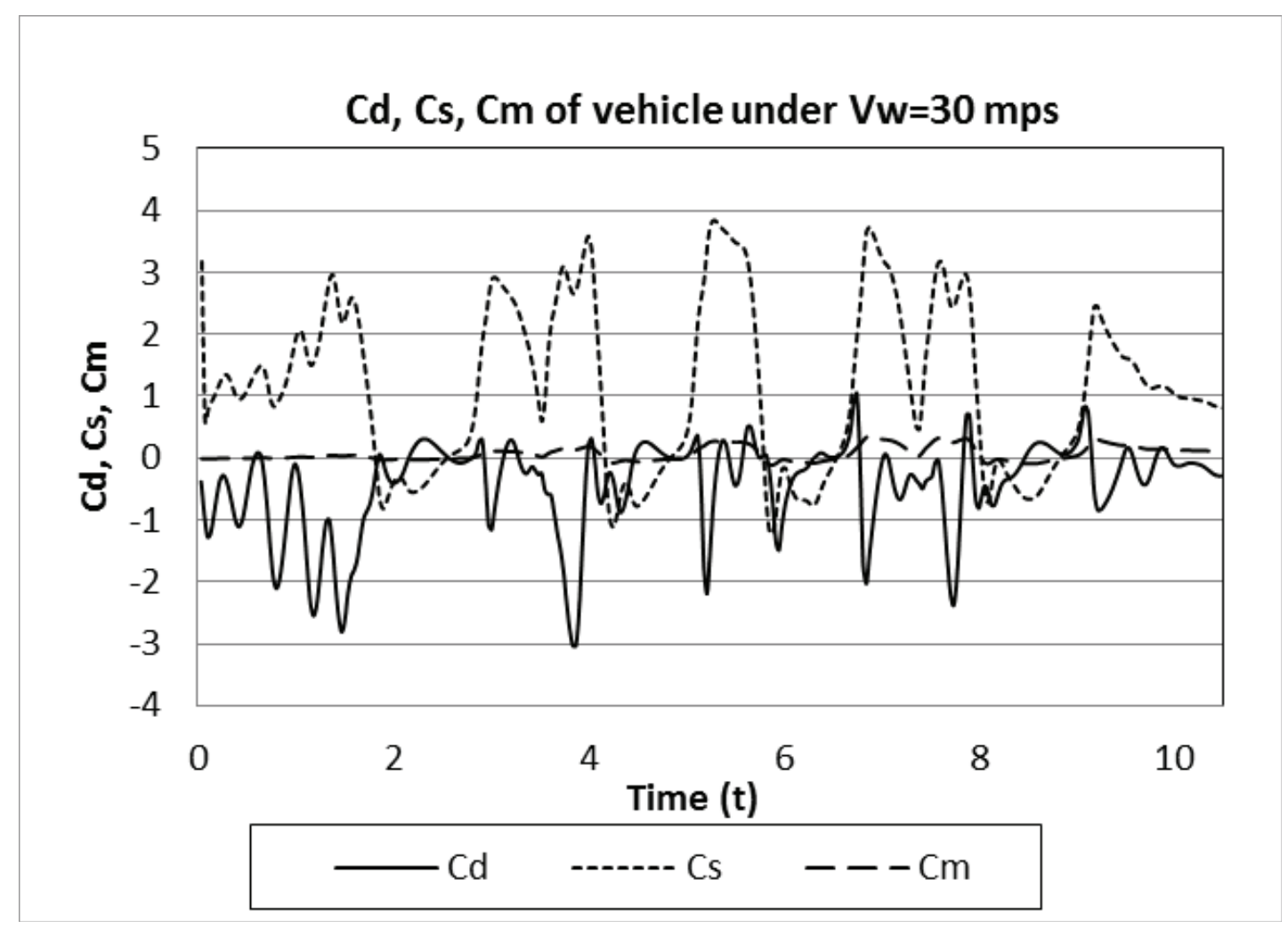

Figure 18: Drag, side force and moment coefficients of vehicle crossing the bridge at $V v=27 m / s$, in under $V w=30 \mathrm{~m} / \mathrm{s}$. 


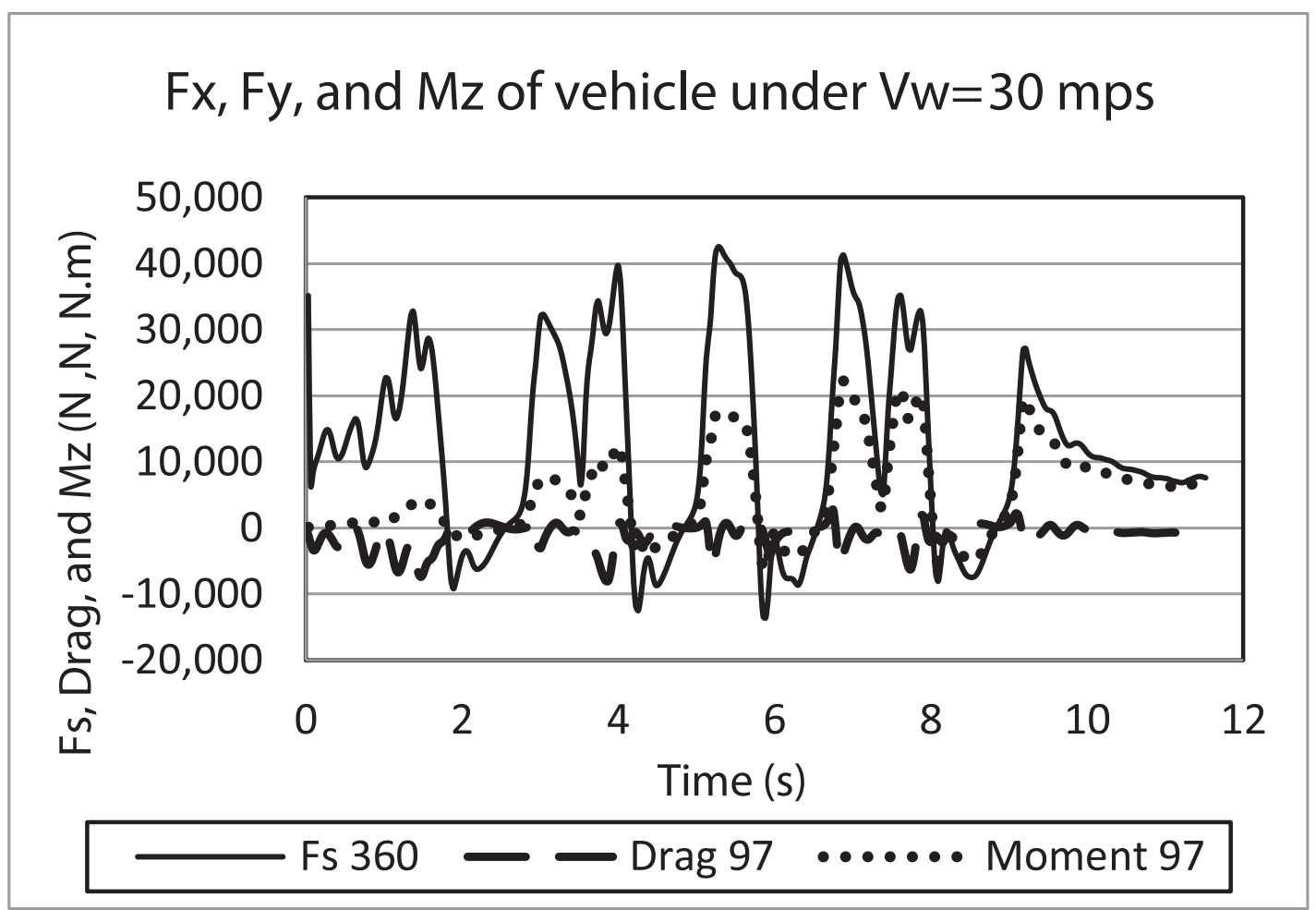

Figure 19: Drag, side forces and moment affecting the vehicle crossing the bridge at $V v=27 \mathrm{~m} / \mathrm{s}$, in under $\mathrm{Vw}=30 \mathrm{~m} / \mathrm{s}$.

\subsubsection{Effect of vehicle forward velocity on aerodynamic forces}

Different vehicle velocities of $(22.22 \mathrm{~m} / \mathrm{s}, 27 \mathrm{~m} / \mathrm{s}$ and $33.33 \mathrm{~m} / \mathrm{s})$ are tested. The obtained forces results are shown in Figures 20 and 21 at vehicle forward velocity $V w=30 \mathrm{~m} / \mathrm{s}$, 90 degree.

\section{Conclusion}

Computational fluid dynamics (CFD) sliding mesh technique method was successfully developed and applied to investigate aerodynamic forces on vehicle moving on bridge while was exposed to transient crosswind. A bicycle vehicle model was used in the simulation. The effect of vehicle and wind velocities on the vehicle handling behavior as a result of the generated aerodynamic forces were investigated. Validation of the results obtained from cross wind and vehicle test models showed successfully agreement with previous literature studies.

The side wind crossing the bridge through region of middle walls of the bridge were found to be three times in velocity than the free stream in the opining region, with large variation in value and direction. Wind direction (attack angle) may change wind 


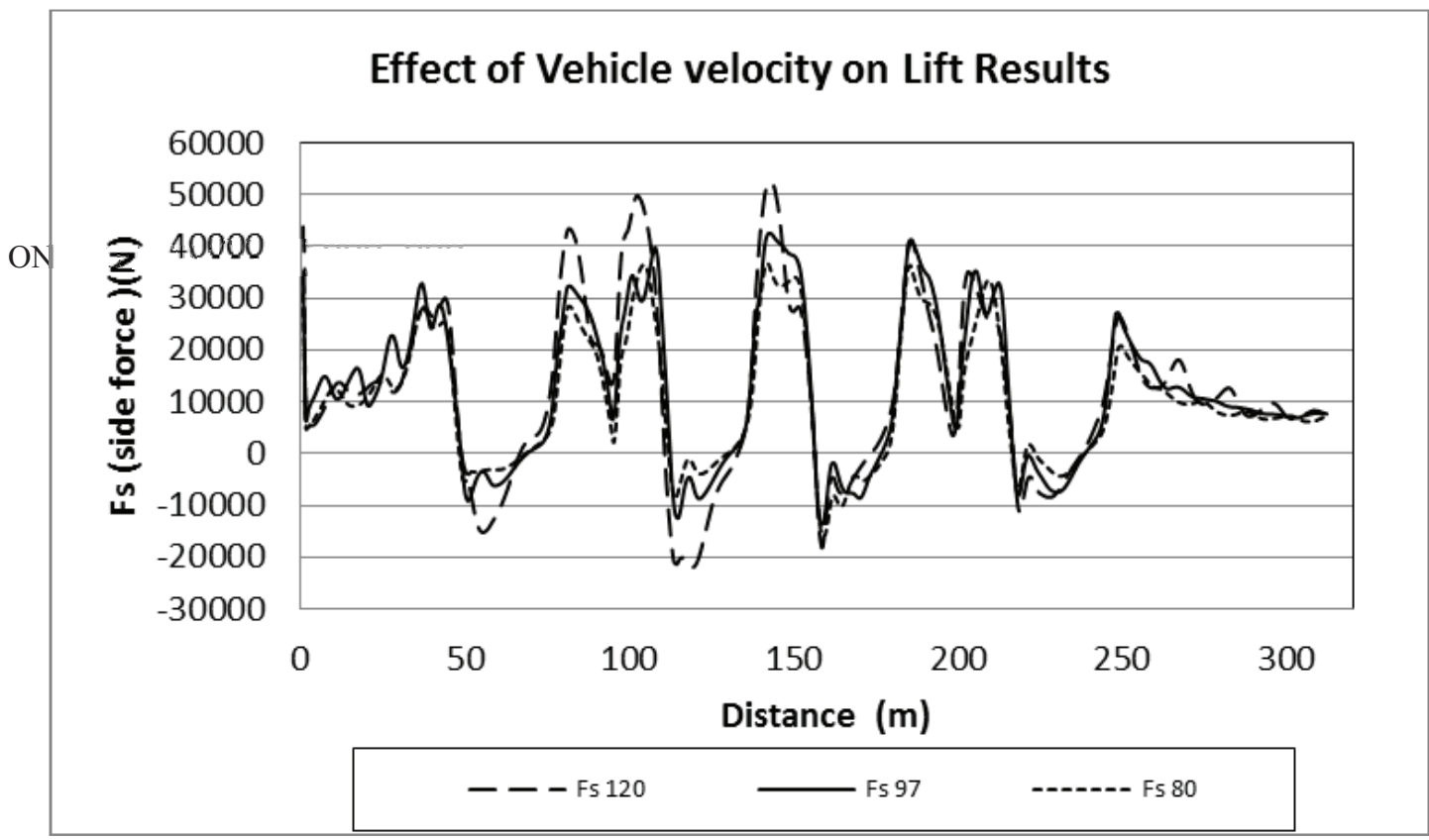

Figure 20: Effect of Vehicle velocity on Side force (Fs) results, at $V w=30 \mathrm{~m} / \mathrm{s}$.

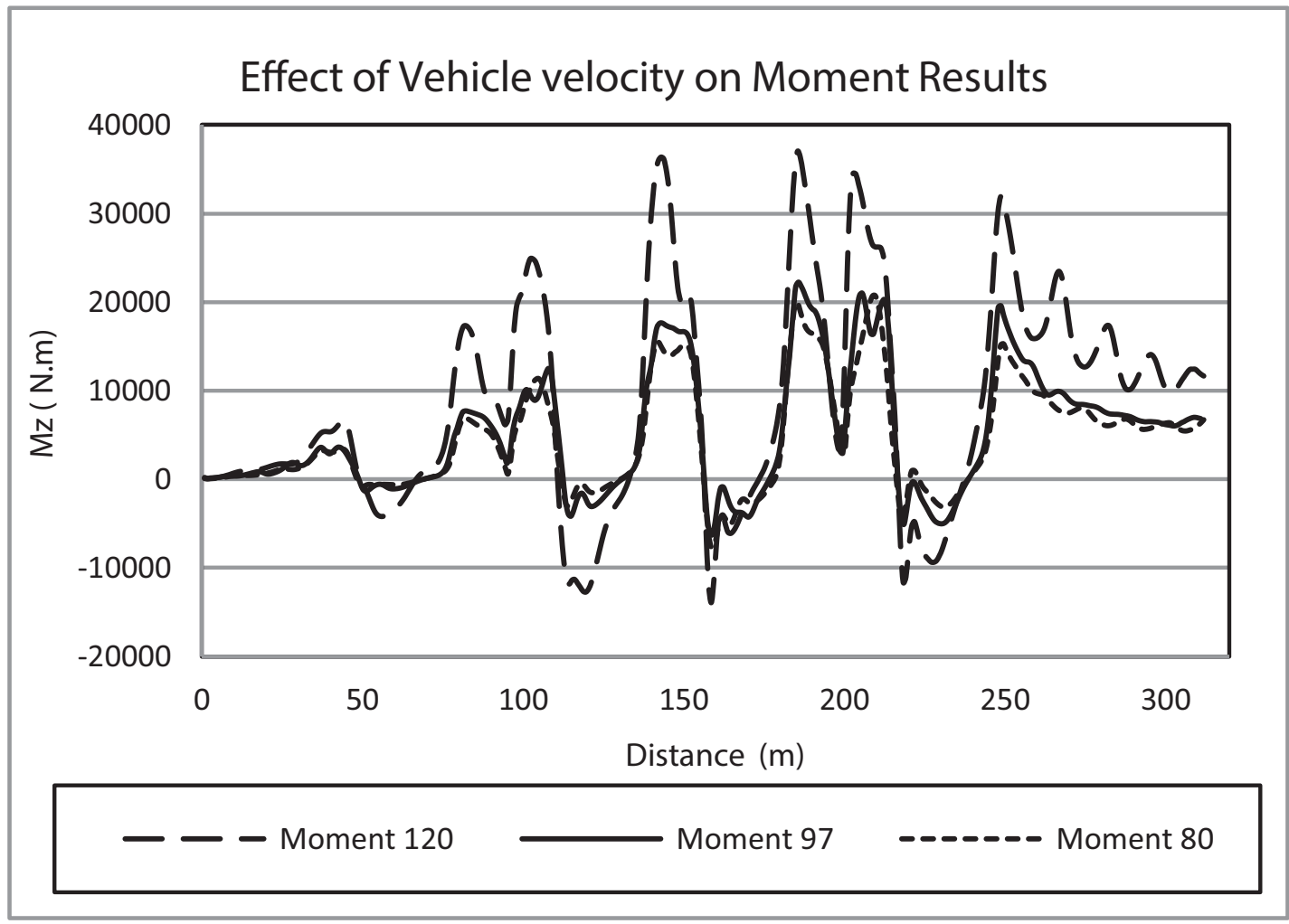

Figure 21: Effect of Vehicle velocity on Moment results, at $\mathrm{Vv}=27 \mathrm{~m} / \mathrm{s}$.

contour after the bridge sails. Maximum values were obtained when the wind was perpendicular to the bridge and side forces have the same pattern. 
Yaw moment was found to have a significant effect on vehicle handling behavior than side force. When vehicle forward velocity reaches $120 \mathrm{KPH}$, the yaw moment increased by about twice the value obtained at vehicle forward velocity $=97 \mathrm{KPH}$ These results agree with those in the literature.

It is recommended in future work to develop a $3 \mathrm{D}$ modelling of wind simulation. This is expected to give deeper understanding of the interaction of the side wind pattern applied on the vehicle.

\section{References}

[1] Al Buflasa, H., D. Infield, et al. (2008). "Wind Resource Assessment for the Kingdom of Bahrain." Wind Engineering 32: 439-448.

[2] Alayam Newspaper (2011), Family car rollover resulted in several injuries: Several people were injured in an accident on the Shaikh Isa bin Salman bridge. [online] available from <http://www.alayam.com/alayam/local/438540/News. html\#ar chive $>$ [ 1 January 2011]

[3] Alayam newspaper (2012a), Ministry of Works: Creating a traffic safety barriers on Shaikh Isa Bridge at a cost of 269,500 dinars. [online] available from <http://www. alayam.com/online/local/142134/News.html\#arc hive> [28 February 2012]

[4] Alayam newspaper (2012b), Implementation of the directives of the Prime Minister: Ministry of Works finished creating barriers bridge Shaikh Isa. [online] available from <http://www.alayam.com/alayam/local/184695/News.html\#ar chive > [15 September 2012]

[5] Alnaser, W.E., and Al-Karaghouli A. (2000), Wind availability and its power utility for electricity production in Bahrain. Renewable Energy, (21) 247-254.

[6] Al-Wasat Newspaper (2003), Bahraini and Asian injury and serious injuries in two separate incidents. [online] available from <http://www.alwasatnews.com/271/ news/read/315426/1.html> [4 June 2003].

[7] Al-Wasat Newspaper (2009a), NZ athlete killed after a collision of a car hit his bicycle [online] available from <http://www.alwasatnews.com/news/9459.html> [9 June 2009].

[8] Al-Wasat Newspaper (2009b), Ministry of Works statistics: Half a million cars a day pass from Manama According to «works» for traffic in 2008. [online] available from <http://www.alwasatnews.com/2509/news/read/173083/1.html> [20 July 2009].

[9] Al-Wasat Newspaper (2010), The death of a young Bahraini and four wounds in a terrible accident on Shaikh Isa bridge. [online] available from <http://www. 
alwasatnews.com/news/436145.html> [21 June 2010].

[10] Al-Wasat Newspaper (2011), 5 people injured in lost control of a car on Sheikh Isa bridge. See the photos. [online] available from <http://www.alwasatnews.com/ news/592238.html> [30 August 2011].

[11] Al-Wasat Newspaper (2012a), Interior Ministry: motorcycle lost control on Shaikh Isa Bridge towards Muharraq. [online] available from <http://www.alwasatnews. com/news/662097.html> [10 May 2012].

[12] Al-Wasat Newspaper (2012b), Interior Ministry: lost control of a car on the Shaikh Isa bin Salman bridge. [online] available from <http://www.alwasatnews.com/3569/ news/read/675259/1.html> [15 June 2012].

[13] Al-Wasat Newspaper (2012c), Interior Ministry: one person injured after he lost control of his car on Shaikh Isa Bridge near Muharraq. [online] available from <http://www.alwasatnews.com/news/718208.html> [23 November 2012].

[14] Al-Wasat Newspaper (2013a), Ministry of Works: the streets of Manama, attracts more than 750 thousand vehicles a day Top Street Khalifa bin Salman density traffic. [online] available from <http://www.alwasatnews.com/3812/news/read/ 738845/1.html> [13 February 2013].

[15] Al-Wasat Newspaper (2013b), Interior Ministry: two people injured by lost control car on Shaikh Isa Bridge. [online] available from <http://www.alwasatnews.com/ news/806624.html> [3 September 2013].

[16] Charuvisit, S. Kimura, K. Fujino, Y. (2004a), Experimental and semi-analytical studies on the aerodynamic forces acting on a vehicle passing through the wake of a bridge tower in cross wind. Journal of Wind Engineering and Industrial Aerodynamics, (92) 749-780.

[17] Corin, R.J., He, L., and Dominy, R.G. (2008), A CFD investigation into the transient aerodynamic forces on overtaking road vehicle models. Journal of Wind Engineering and Industrial Aerodynamics, (96) 1390-1411.

[18] European Agency for Safety and Health at Work (2010), A Review of Accidents And Injuries To Road Transport Drivers. Luxembourg: Publications Office of the European Union.

[19] Haji Hassan ReadyMix (2012) Sheikh Isa Bin Salman Causeway [online] available from <http://www.hajihassanreadymix.com/gallery.php?page= Sheikh_Isa_Bin_Salman_Causeway> ['n.d.'].

[20] Hucho, W.-H. and Sovran, G. (1993), Aerodynamics of Road Vehicles. Annual Rev. Fluid Mech, (25), 485-537. 
[21] Institute for Road Safety Research (C Swov (2012), Swov Fact Sheet: The Influence Of Weather On Road Safety.

[22] Leidschendam: Institute for Road Safety Research Rocchi, D. Rosa, L. Sabbioni E. Sbrosi, M. and Belloli, M. (2012), A numerical-experimental methodology for simulating the aerodynamic forces acting on a moving vehicle passing through the wake of a bridge tower under cross wind. Journal of Wind Engineering and Industrial Aerodynamics, (104-106) 256-265.

[23] Sims-Williams, D. (2001) Self-Excited Aerodynamic Unsteadiness Associated with Passenger Cars, Durham theses, Durham University. [online] Available at Durham E-Theses Online <http://etheses.dur.ac.uk/7297/>

[24] Society of Automotive Engineers, (1965) 'Effect of Unsymmetrical Wind Incidence on Aerodynamic Forces Acting on Vehicle Models and Similar Bodies'. Paper 650136, 1965, doi:10.4271/650136. Barth, R., Society of Automotive Engineers

[25] Wong, J. (2001). Theory of ground vehicles New York: A Wiley-Intersc ince Publication. 